\title{
THE SMITHSONIAN INSTITUTION.
}

Mr. Long presented the following

\begin{abstract}
ARTICLE ENTITLED "THE SMITHSONIAN INSTITUTION," BY CHARIES MINOR BLACKFORD, JR., IM. D., REPRINTED FROM THE WORTH AMERंICAN REVIEW FOR JANUARY, 1909, WITH REVISIIONS BY THE AUTHOR.
\end{abstract}

February 15, 1909.-Ordered to be printed.

THE SMITHSONIAN INSTITUTION.

Situated in the city of Washington is an organization which is ique among learned establishments in aims, objects, methods, and gin. It is controlled by the Congress of the United States, but it governed by rules of its own making. It is a society with no nber and but a few associates; a university without a faculty, that has no matriculates and grants no degrees; a great publishing house that pays nothing for manuscripts, holds no copyrights, and gives away the greater part of its output. This is the Smithsonian Institution, an establishment little understood by the people, although to it is due, in large measure, the high rank held by American scientific workers throughout the world.

The origin of this remarkable organization is not its least peculiar feature, for it was established in accordance with the will of James Smithson, an English chemist, who left a legacy to the United States for the purpose. Legacies to governments are rare, and legacies by a. subject of one country to the government of another are so uncommon as to arouse interest in the personality of the donor and the motives that prompted such an act.

James Smithson was a natural son of Sir Hugh Smithson, who was created Duke of Northumberland in 1766 and assumed the name of Percy. The son, who was to make the former name illustrious, was born in France in 1765, and bore his maternal name of Macie throughout his early years, probably assuming that of his father on coming of age. He was one of the memorable group of investigators who freed chemistry and physics from the superstitions and follies of alchemy and magic that hung about them for so long. Cavendish was one of his intimate friends, as was Arago at a later period; but 
his correspondence embraced almost every man of scieli. in Europe. His work in chemistry and mineralogy attra.. tion, and he became a Fellow of the Royal Society, to whose sophical Transactions" he contributed several papers. He wàs a voluminous writer, and many of his unpublished papers came hito the possession of the Smithsonian Institution with his other personal belongings, but, unfortunately, were almost entirely destroyed in a disastrous fire in 1865 .

Burdened by ill health, he was forced to seek a more genial clime than that of England, and his later years were passed on the Piviera. In 1826 he made his will, by which his entire estate, with the exception of a few private legacies and certain specified contingencies, was bequeathed to the .United States "to found at Washington, under the name of The Smithsonian Institution, an establishment for the increase and diffusion of knowledge among men." His reason for selecting the United States for this purpose is not known. The Federal Republic was still an experiment, and few European statesmen beliered it to be permanent. By his gift, Smithson shiswed his faith in its stability; but it is none the less strange that his bounty should have been so bestowed, as he had no ties in America and had never even paid it a visit. It is said that the advice in Washington' farewell address that the people of the United States should promote "as an object of primary importance, institutions for the general diffusion of knowledge," accorded with his own opinion of the duty of a nation.

The will became operative at the death of its maker, which occurr at Genoa in 1829, and the income of the estate went to Smithsor nephew, Henry James Hungerford, until the death of the latter, June 5, 1835. The bequest of the property to the United St: thereupon became operative, and in September, 1835, the Stes Department received notification therenf. On the 17 th of vecertater President Jackson informed Congress of the bequest, and on July 1 , 1836, the gift was accepted and the President empowered to appoint an agent to collect the money. Richard Rush, of Penusylvania, iv as intrusted with this duty, and in November he brought the necessarily formal suit in the English court of chancery, where the claim remained for two years. Upon the final interpretation of the will, Rush returned to America, bringing the fund with him. In his report he states that he brought it in 105 bags, each containing 1,000 sovereigns, except one that held 960 sovereigns; and, with laughable accuracy, he adds, "eight shillings and sevenpence wrapped in paper," all of which was deposited in the mint in Philadelphia on September 1, 1.:3S.

The sum so deposited was equivalent to $\$ 508,318.46$, and at once suggestions were offered for its expenditure in accordance with the terms of the will. As these rere somewhat indefinite, it is not surprising that the proposals were varied in character. A national library, a national university, a national gallery of art, and an astronomical observatory were among the suggestions, but all these were rejected; and in 1846, after eight years of exhaustive deliberation, the present establishment, fulfilling in a measure the functions of all the above suggestions was brought into being by an act of Congress that rendered the income of the fund available under the management of a board of regents. The first meeting of the 
1egents for the pulpose of organization was held on September 7 , 1S46, when Prof. Joseph Henly was elected secretary of the nstitution.

As stated in his will, the founder wished liis bequest to be used to increase and diffuse knowledge among men. It therefore follows that the institution is international, and that its benefits ale not to be restricted to the United States, our Government being merely a trustee for the human race. As the Government can not administer this trust directly, there was constituted by Congress an establishment consisting of the President, the Vice-President, the Chief Justice, and the heads of the executive departments of the United States. These are known as "members of the institution." For conducting the business of the institution a board of directors was created, called a board of regents, to which the management of the income of the fund was intrusted and from which an annual report is required. The board of regents virtually have full powers, subject to the general laws of the land. As now constituted, the board consists of "the Vice-President, the Chief Justice of the United States, three members of the Senate and three Members of the House of Representatives, together with six other persons other than Members of Congress, two of whom shall be resident in the city of Washington, and the other four shall be inhabitants of some State, but no two from the same State." This board of regents elects the secretary, to whom is given full administrative power to carry out the aims of the institution.

As said above, these aims are to increase and diffuse knowledge; and, as a private establishment with means of its own, the institution is admirably fitted for carrying them out. The relation of gorernments to abstract research is a question on which political economists are not agreed. The safest rule is to extend public aid after some definite result has been accomplished, as is done through patents and copyrights, for discretionary power in such a matter would open the way to gross abuses. On the other, hand a body like the Smithsonian Institution can discriminate, and is not so liable, therefore, to be despoiled, while genuine students are sure of a sympathetic hearing and of assistance of the sort they most need.

Professor Henry did much to advance the great invention of the middle of last century, the electric telegraph. As far back as 1827 he had discovered that, if a weak electrical current were passed through a silk-covered wire wrapped repeatedly about an iron core, a far greater lifting power would be given the resulting magnet than was possessed by any electro-magnet previously known. In $182 \mathrm{~S}$ he exhibited before the Albany Institute a small magnet similar to those in use at the present day, and in 1831 he explained the difference between a "quantity" magnet, excited by a "quantity" battery of a single pair of elements, and a "quality" magnet excited by a number of cells, pointing out at the same time that the latter was the form to be used for telegraphy. Peter Barlow had claimed that a galvanic current became so weakened after traversing 200 feet of wire that it would not produce magnetism, and that, therefore, an electric telegraph could not be operated over a single mile of wire. Henry claimed that Barlow's magnet was improperly arranged, and to demonstrate this he suspended 1,060 feet of common bell wire about the walls of the academy at Albany, with a battery at one end and one of 
his magnetic coils at the other. The armature was arranged to strike a bell and make a signal. The demonstration was complete, and to him is due the first electro-magnetic telegraph ever constructed.

Such was the man who for more than thirty years directed the course of the institution. In that time he fixed the lines on which it should move, and defined its part in the scientific development of the world. His successors, Baird, Langley, and Walcott, have pursued the policy he laid down, and it is due to this policy that the institution has won and holds the friendship of all other learned bodies, with which it is ever an earnest cooperator, without jealousy or rivalry. Every branch of human thought has felt the influence of the workers connected with it, and many of those who have made and are making America stand abreast of the world in science have been spurred to activity by the genial enthusiasm and kindly sympathy of those within its walls.

The Louisiana purchase gave to the United States a vast tract of unknown territory, to which the results of the Mexican war made large additions. In 1846, the greater part of the region west of the one hundredth meridian was unexplored, but the discovery of gold caused such a rush of settlers across the continent that its survey became a necessity. Between 1849 and 1854, the War Department sent sereral parties through these unknown regions to find practicable routes for railways. The opportunity so presented was grasped by the Smithsonian Institution, and botanists, geologists, zoologists and ethnologists accompanied the expeditions. The results of these explorations were published in the magnificent series of Pacific Railway Reports; and, although these were issued under the auspices of the Mar Department, they may be ascribed to the Smithsonian Institution without impropriety. The surveys under Prof. F. V. Hayden and Maj.J. W. Powell were aided by money from its funds, as well as by representations to Congress that secured the appropriations needed for their prosecution.

The wisdom of these acts has been proven by the results that have followed. The surfers dispelled the notion of "the Great American Desert," and showed a fertile country where a sandy waste had been thought to exist. They proved that the Rocky Mountains were neither impassable nor inaccessible, but were easily reached, and were filled with minerals of inestimable value. To the artist they revealed scenery that Europe can not rival; to geologists they showed wonders whose like had never been seen, canyons with walls more than a mile in rertical height, geysers, and marvelous natural sculptures that are unequaled in the world, and beds of former inland seas that hold, as fossils, remains from which the history of life on earth has been deciphered. Ethnologists sent by the Smithsonian Institution have found that this continent was once inhabited by races of men who raised massice mounds in fantastic shapes in which are buried memorials of long-forgotten peoples. They discorered and described the strange homes built by the "cliff-dwellers" in rifts of the solid rock. They observed and recorded the customs, manners, rites and religion of the aborigines, and collected their myths, traditions, and superstitions before contact with alien beliefs corrupted their integrity. They studied the remains of great structures built by the Aztecs and other ancient peoples in Mexico, Central and South America. By these researches, directly under the 
Institution and through its Bureau of American Ethnology, a new field was opened to science and civilizations centuries old were revealed and compared with those already known.

The practical value of these surveys was so apparent that many far-seeing men urged their extension over the whole country. It is evident that work of this description can be done only under national direction, for the methods must be uniform and the results, to be of value, must be reported in the same terms. Beds of ore and other geological formations pay little attention to political boundaries, and only Federal officials can carry investigations to conclusions without hindrances of this sort. The geological division of the Institution cooperated fully with the surveys of the War Department, until they were suspended by the outbreak of the civil war. After the restoration of peace, the enormous development of the West brought demands on the Smithsonian Institution that its scanty means were unable to meet. As its reports had been the chief means by which the natural wealth of the Western country had become known, it was called on to make the knowledge more perfect, and, however willing, it could not respond to the demand. At last, Congress came to the rescue, and in 1879 the Geological Survey was established to make a systematic study of the whole country. The magnificent series of reports, bulletins, charts and monographs that have issued from this bureau may, without injustice, be regarded as fundamentally due to the Smithson foundation.

While this great work was in progress, Professor Henry was organizing a force to make systematic observations of meteorological conditions. Before the Revolution, Thomas Jefferson, afterwards President of the United States, and James Madison, then President of William and Mary College and later Bishop of Virginia, maintained a correspondence in which each informed the other continuously of the atmospheric conditions that prevailed in his locality. Jefferson was at his home near Charlottesville, amid the foot hills of the Blue Ridge, and Madison was in Williamsburg, in the tide-water section of the Colony, some 120 miles distant. They arranged for simultaneous observations of thermometric and barometric readings, the direction of winds and such other phenomena as they could record with accuracy with the limited apparatus at command. This was the first experiment of this character, and the original correspondence and records, now on file in the archives of the State Department, show that the idea of an organized weather bureau originated with these cultured men long before it was developed in France.

In 1849 Henry established the Smithsonian meteorological system. The work of Maury on the winds and currents of the sea had shown that such investigations are practicable, and the writings of Espy and others created a demand for similar investigations on land. Henry enlisted the aid of volunteer observers throughout the country who were willing to serve without pay, and a vast store of material was accumulated. The Medical Department of the army cooperated with the civil volunteers, and the institution supplied instruments so that the observations might conform to a uniform standard. A result of this undertaking was that a great number of people in the country became interested in meteorology, and helped to orer- 
come the opposition that superstition and ignorance offered to its progress. The telegraph companies gave generous assistance, and the practical value of the storm warnings soon silenced the most bigoted opponent of the system.

The quantity of data quickly became immense, and, as soon as a sufficient amount was on hand, the work of reducing it to scientific form was begun. The discussion of temperature and rainfall was assigned to Charles A. Schott, now celebrated for his researches into terrestrial magnetism, who arranged the hourly, bihourly, and semihourly observations of temperature in such a manner that from them tables might be deduced for the correction of daily variations in temperature. He also compiled an elaborate set of tables showing the rainfall in different parts of the country as far back as trustworthy information could be had. Prof. J. H. Coffin, of Lafayette College, undertook the work on the winds, and in 1853 his book, The Winds of the Northern Hemisphere, was published. After his death his Winds of the Globe appeared, edited by his son and by the Russian meteorologist, Woeikoff. To meet the expense of these works and to pay for labor other than that of Professor Coffin, the Smithsonian Institution made appropriations from its own income, and thus established the infant science on a sure footing. It began the publication of daily weather maps in 1556 , two years before Leverrier began the publication of the Bulletin International, and seven years before the weather map was added to it - a fact overlooked by so compendious a work as the Encyclopædia Britannica. The cost of this service steadily increased as it enlarged its scope, and it became too great a burden for the limited means of the institution to bear; and in 1869 Congress established the Weather Bureau, placing it under the charge of the War Department. The practical utility of this bureau is so thoroughly recognized that it need not be more than mentioned; but not the least of its services has been freeing the minds of the people from the superstitions and follies that invested the whole subject for so many ages, and showing that the same natural law that prevails in the rest of the universe controls the winds and rains as well.

Professor Henry instituted in this country the plan of simultaneous observations devised by Leverrier in France, and all of the observers noted the readings of the thermometer, barometer, and other instruments at certain fixed hours.

In 1845 Sir John Franklin made an attempt to discover the famous "northwest passage" from the Atlantic to the Pacific along the northern coast of America. The expedition was well equipped, and was provided with the two ships Erebus and Terror, but its precise fate is one of the mysteries of the sea. In 1848 the British public began to feel uneasiness about the expedition, and search parties were organized to try to find out what had become of it. The same generous sentiment moved the American people, and Mr. Henry Grinnell, of New York, equipped the Advance and the Rescue to aid in the search. These vessels sailed in 1850, commanded by Lieutenants De Haven and Griffith, and accompanied by Dr. Elisha Kane, one of the most celebrated of arctic adventurers. Professor Henry saw in this expedition an opportunity for research into the climatic conditions of the polar regions. The liberality of Crinnell had been reenforced by a grant from Congress, and this enabled the Navy Department to assume management and to detail its officers from the 
regular service. The Smithsonian Institution supplied these officers with the necessary instruments, and to their reports is due the first accurate knowledge that the world gained of the meteorological conditions of the Arctic Zone. The subsequent voyages of Kane, Hayes, and others; the disastrous expeditions in the Polaris and the Jeannette, and the later travels of more fortunate explorers, have furnished data from which those who penetrate these forbidding realms may learn in advance the obstacles and perils with which the weather may threaten them. Those of us whose ambitions lie in other lines may learn the causes of winter storms, and, when the causes have been fully shown, may find some preventives.

As the work of the institution became steadily wider in scope and greater in volume, the labor entailed on its secretary increased until it grew too vast for his performance. In 1850 Professor Henry asked the regents for authority to appoint an assistant who should take charge of the department of natural history and of the infant National Museum. The request was granted, and Prof. Spencer Fullerton Baird, then of Dickinson College, Carlisle, Pa., was offered the post. Two years previously he had applied for and had been granted the first appropriation made by the institution for original research, and the sum so obtained had been applied to the exploration of bone caves in southeastern Pennsylvania. This incident seems to have been the thing that attracted Henry's attention to the young scientist and, as further acquaintance ripened the respect of each for the other, the offer and its acceptance were pleasing to both. To Baird fell a large part of the responsibility of developing the various departments, and two great agencies have sprung from his labors. Although but one of these is still under the wing of the parent establishment, both take pride in their great founder, and the one that is now independent delights to use its freedom on behalf of its noble parent. These two agencies are the Smithsonian international exchange service and the United States Commission of Fish and Fisheries.

The Smithsonian international exchange service originated from a suggestion made by Henry and was adopted at a meeting of the regents on December 8,1847 . It was merely a plan for the enrichment of the library by exchanging the publications of the institution for those of scientific bodies abroad, thereby performing the duty of diffusing knowledge among mankind. The labor of oroanizing and starting the system into operation was done by Henry himself, but when Baird became assistant secretary he assumed charge of the exchanges and brought it to its present state of efficiency. BV means of the foreign correspondents of the institution, packages intended for exchange abroad were delivered to their consignees and the articles received in return were brought back and delivered without cost and without annoyance. At first this service was solely in the interests of the institution, but Baird soon extended it to societies, colleges, and individuals, and set about a task that would increase its value immeasurably. When the system was inaugurated the annoying delays and the expenses occasioned by the requirements of the custom-houses added so greatly to the burden as to make it almost more than the institution could bear, and the new assistant secretary determined to remedy the evil. He interested intelligent men throughout the country, and then made persistent and concerted efforts that induced Congress to adopt the enlightened policy of adnitting through 
the custom-houses, free of all duties, scientific publications or other articles addressed to the Smithsonian Institution, whether for its own use or for that of its correspondents. Stimulated by this success, foreign societies urged similar action on their respective governments with such effect that Professor Henry was able to say, in his report for 1854: "There is therefore no port to which the Smithsonian parcels are shipped where duties are charged on them, a certified invoice of contents by the secretary being sufficient to pass them through the custom-house free of duty. On the other hand, all packages addressed to the institution arriving at the ports of the United States are admitted, without detention, duty free. This system of exchange is, therefore, the most extensive and efficient which has ever been established in any country."

The utility of the exchange service was soon recognized, and those benefited by it availed themselves of its advantages to an extent beyond the arailable means of the institution. A circular was sent to the principal transportation companies in 1855, explaining the objects of the service, and asking aid in the form of a reduction of rates. The replies show the high appreciation of science in America, for, while some offered a merely nominal rate, the greater number cheerfully agreed to transport the packages free of all charges whatever. This generosity enabled the service to be maintained for the time being, but its expense was still so great that curtailment seemed inevitable in this or some other part of the work that was being done so unobtrusively. The Department of State tried to persuade Congress to assume part of the burden, but it was not until 1881 that the sum of $\$ 3,000$ was granted for this purpose. The amount was small, but it was a great help and gave promise of annual appropriations in the future.

The publications of our Government and of those of foreign countries are often of the utmost importance to students, but it is difficult for libraries or individuals to obtain those issued abroad. In 1867 Congress ordered that 50 copies of all governmental publications should be put at the disposal of the Joint Committee on Library for exchange through the Smithsonian exchange service for such works published abroad, especially by foreign gorernments, as the committee may consider a fair equivalent, and that such works received in exchange shall be deposited in the Library of Congress. It is apparent that this really threw the cost of making such additions to the Library of Congress on the institution, and in 1876 this expense reached $\$ 10,000$-nearly one-fourth of its total income. It was on this account that Congress was mored to aid in the work, but since the time that these appropriations hare been available the institution has been compelled to advance from its slender funds amounts that aggregate $\$ 45,175.82$ for the transportation of gorernment documents, not one cent of which has been refunded.

The figures for the fiscal year 1907-8 give an idea of the enormous mass of matter handled by this bureau. From the published report it appears that 203,098 packages, aggregating 435,285 pounds, were handled during the year. There were shipped to foreign countries in exchange on behalf of the various departments of the United States Government 102,694 packages, while domestic societies and individuals received 27,671 parcels, all of which were delivered at their destinations free of all costs to their recipients. The total 
number of correspondents in 90 countries at the close of the year was 60,123. The figures speak for themselves, and show the part played by this wonderful organization in the "diffusion of knowledge among men."

A full consideration of the work and usefulness of the United States Commission of Fish and Fisheries would be out of place in this paper, but no account of the Smithsonian Institution is complete that does not contain a reference to its begimning. The depletion of the fisheries of our coast and inland waters became so apparent that Congress was moved to take action looking to their restoration. In 1871 a bill was passed authorizing the President to appoint a civil servant of the Government who had a practical and scientific acquaintance with fish and fisheries to inquire into the decline, to ascertain if it was real or apparent, and to suggest means for checking: it. No pay was to be given for this service, and, although not named in the bill, there was but one man who could fulfill its requirements. This was Professor Baird, and, after being duly appointed by President Grant, he assumed the duties of the office. The appointment was a happy one in every respect, and in nothing was Baird's genius for administration seen to better advantage. No such bureau existed in the world; indeed, even so late as 1884, Mr. Huxley, writing of the exhibit of the Fish Commission at the Great International Fisheries Exhibition in London, said that it is an establishment "whose precise parallel it is impossible to find in Europe," but so broad and true was the foundation on which Baird placed it that the enviable position of practical and scientific efficiency that it now occupies has been attained by following the precepts laid down for it by its founder when such a bureau was an experiment. Although no longer officially associated with the Smithsonian Institution, the two bodies are united by the closest ties of friendship and are in hearty cooperation.

Probably most of the visitors to Washington think of the Smithsonian Institution in connection with the National Museum, and many of those who go to the museum think it identical with the institution. The connection of the two is most intimate, but they are distinct organizations, the National Museum being supported by the Govermment and its employees are salaried officials of the United States, while the institution, as explained above, is a private establishment supported by its own means. Its relation to the museum can best be understood in the light of the history of the latter organization.

In 1840 there was a society organized in Washington under the name of the "National Institution," a title afterwards altered to the "National Institute." For four years the society was very prosperous and possessed a numerous and influential membership. It gathered the nucleus of a national museum which it deposited in the Patent Office building, but its greatest service was the cuitivation of the idea that such an enterprise was worthy the attention of the United States. The society tried to obtain official recognition, but its efforts failing in 1846 , it became inactive, and finally passed out of existence in 1861. The Sinithsonian Institution was organized during its term of life, and one of the bequests to the new establishment influenced the fate of the museum. This was a cabinet of minerals collected by Smithson, and as the institu- 
tion had to care for it the governmental collections were also put into its charge, when, in 1858 , the "National Institute" surrendered what was called the "National cabinet of curiosities." The deposits in the Patent Office were remored to the Smithsonian building, and the government collections have since been known under the name of the National Nuseum. Br the original act of foundation, in 1846, the Smithsonian Institution was made the lawful depository of all the material collected by the different departments of the Government; but while liberal in assigning duties, Congress was not so thoughtful in proriding for the costs of caring for the collections. The loving zeal of indiriduals supplied this lack in large measure, and the work of assorting and arranging the accumulation of materials was performed gratuitously by colunteers, some of whom were of worldwide reputation in their several specialties. Duplicate sets of specimens illustrating the different branches of science were prepared and arranged in systematic order, and were either exchanged for those lacking in the museum, or were giren to colleges, local museums, and individuals carrying on original investigations. The funds of the institution were insufficient to pay for such work, and the public owes a debt of gratitude to those who, like Cones, Cope, Ridgway, Gill, and others, gave time and toil to performing a labor of love. By 1870 the proportion of the total income of the institution, amounting to $\$ 45,489.38$, that must be deroted to sustaining the National Nuseum had become so great as to seriously cripple the institution in carrying on its own functions. In $1872 \$ 15,000 \mathrm{was}$ appropriated by Congress for this purpose, and repeated annually for several years. The annual appropriation is now sufficient, with close economy, to meet the current expenses, but there are no funds with which to purchase accessions, and the growth of the collections depends on the activity of other bureaus and the liberality of individuals. Despite this hindrance, the museum now contains about three and a half million objects.

Under the direction of the board of regents there hare also been placed three gorernment interests which, like the museum, were at first supported by the funds of the institution. These were established during the administration of the late Secretary Langley. They are the National Zoological Park, created "for the advancement of science and the instruction and recreation of the people," situated on the outskirts of Washington, and containing some 1,400 specimens of animals from all parts of the world housed in surroundings as natural to them as possible; the Astrophysical Observatory, deroted to the study of the sun's heat and its effect on the earth, and similar problems: and the regional bureau for the United States of the International Catalogue of Scientific Literature, which indexes and catalogues the scientific publications of this country for the use of those engaged in research and others. These interests are now supported by annual congressional appropriations administered by the secretary of the institution.

No sketch of the Smithsonian Institution should close without a mention of its publications. There are many works whose publication is demanded by the growth of science, but for which the demand would be so limited that no commercial publisher would be justified in issuing them. Such works are published by the institution, and are either distributed gratuitously or are sold at nominal prices to those who require them. 
The publications are in several forms. The annual report contains a statement of the operations of the establishnent for the year, and an appendix in which are papers of a somewhat popular nature that bear on almost every field of human thought. A similar report is issued by the National Museum, in which until a few years ago, there was embodied a series of articles based on the collections and of interest to others than professional scientists. The next series is made up of the Smithsonian Contributions to Knowledge, a set of works that has run into thirty-three volumes, in whose pages is recorded the history of the human intellect for the past half-century. Less dignified than the Contributions, but not less important, are the proceedings of the National Museum. a periodical containing technical papers on various subjects and intended to supply prompt publication to suitable essays, and the Smithsonian Miscellaneous Collections, whose nature is sufficiently indicated by the name. Finally come the bulletins, monograghs on different subjects of so high a character that several of them are recognized authorities of the highest order in their respective lines. To these publications is due the wide diffusion of scientific knowledge among the people of the United States, for they go to all parts of the country and are the only scientific papers that reach the masses of the people.

Such has been the result of a single benefaction of half a million of dollars, and perhaps no such result has ever been accomplished by so limited an endowment. Were the great sums given to swell the almost infinite endowments of some of our universities diverted to this unostentatious establishment, its power for good would be immeasurably increased, but, as it is, the bounty of a stranger and an alien has given the American people an agency for good whose influence is incalculable. It presents an opportunity to those who wish to bestow money for some beneficent purpose such as is given by no other on earth, and its scant means and petty endowment are a reproach to our rich and generous nation. 


